\title{
Sensitivity of biogenic carbon export to ocean climate in the Labrador Sea, a deep-water formation region
}

\author{
Ru Cheng $\operatorname{Tian}^{1}$ \\ Ocean Sciences Center, Memorial University of Newfoundland, St. John's, Newfoundland, Canada
}

\author{
Alain F. Vézina \\ Department of Fisheries and Oceans, Bedford Institute of Oceanography, Dartmouth, Nova Scotia, Canada \\ Don Deibel and Richard B. Rivkin \\ Ocean Sciences Center, Memorial University of Newfoundland, St. John's, Newfoundland, Canada
}

Received 12 August 2002; revised 12 May 2003; accepted 24 July 2003; published 3 October 2003.

[1] We used a physical-biogeochemical model to examine the sensitivity of biogenic carbon export to ocean climate in the Labrador Sea, a subpolar, deep-water formation region. Documented changes in winter mixed layer depth between the late 1960s and the mid-1990s were used to construct scenarios of weak, moderate, and strong winter convection that drive the biogeochemical model. The model simulations suggest that the total biogenic carbon export (particle sinking flux + DOC export) is higher under strong winter convection (e.g., during the early 1990s) than under weak winter convection (e.g., during the late $1960 \mathrm{~s}$ ), by $\sim 70 \%$ axcross the $200-\mathrm{m}$ isobath and nearly double at $500 \mathrm{~m}$ and $1000 \mathrm{~m}$ depth. These large variations in total biogenic carbon export are essentially due to the response of DOC export to ocean climate conditions. Sensitivity analyses indicate that the variations in DOC export from the euphotic zone are due to the impact of the convection regime on the development of the microbial food web and on the bacterial consumption of DOC in surface waters. Although DOC downward fluxes within the mesopelagic zone (below $\sim 500 \mathrm{~m}$ ) are largely controlled by physical processes, the effect of convection on microbial dynamics can potentially amplify the year-to-year variations in the transport of DOC to the deep ocean due to

convection. INDEX TERMS: 4215 Oceanography: General: Climate and interannual variability (3309); 4255 Oceanography: General: Numerical modeling; 4806 Oceanography: Biological and Chemical: Carbon cycling; 4840 Oceanography: Biological and Chemical: Microbiology; KEYWORDS: sensitivity analyses, carbon export, ocean climate, microbial food web, deep-water formation, Labrador Sea

Citation: Tian, R. C., A. F. Vézina, D. Deibel, and R. B. Rivkin, Sensitivity of biogenic carbon export to ocean climate in the Labrador Sea, a deep-water formation region, Global Biogeochem. Cycles, 17(4), 1090, doi:10.1029/2002GB001969, 2003.

\section{Introduction}

[2] In subpolar oceans such as the Labrador Sea, dissolved and particulate biogenic carbon is transported to the deep ocean during deep convection in winter [Hansell and Carlson, 1998; Le Quéré et al., 2000]. Simulation models and field studies suggest that the Labrador Sea is an important sink of anthropogenic $\mathrm{CO}_{2}$ [Tans et al., 1990; Takahashi et al., 1995], accounting for 8-19\% of the global deep carbon sequestration [Tait et al., 2000]. Energetic vertical mixing in subpolar oceans during winter can advect nutrients to surface waters, leading to high rates of biological productivity and subsequent downward transport of \footnotetext{
University, Cambridge, Massachusetts, USA.

Copyright 2003 by the American Geophysical Union. 0886-6236/03/2002GB001969
}

${ }^{1}$ Now at Department of Earth and Planetary Science, Harvard organic carbon [Moore et al., 2002]. However, the intensity of wintertime deep convection is subject to climate variations, which can subsequently generate variability in biological production and biogenic carbon export [Gruder et al., 2002].

[3] The climatic conditions over the Labrador Sea are strongly linked with the North Atlantic Oscillation (NAO), an atmospheric mode of variability which is generally described by the winter NAO index based on the difference of normalized atmospheric pressures between Lisbon, Portugal, and Stykkisholmur, Iceland [Hurell, 1995]. Warmer weather over the Labrador Sea and the northwest Atlantic occurred during the late 1960s when the mean value of the NAO index was -1.78 , whereas cold weather prevailed this region for the period 1990-1995 with an average NAO index of approximately +3 [Hurrell, 1995; Dickson et al., 1996]. The warm weather in the late 1960s was associated with the Great Salinity Anomaly over the subpolar gyre in 
the North Atlantic, representing $1.4 \mathrm{~m}$ of fresh water at the ocean surface [Dickson, 1995]. The warm weather, combined with the Great Salinity Anomaly, completely changed the hydrodynamics of the water column [Dickson, 1997]. The winter convection depth in the Labrador Sea was restricted to the upper $200 \mathrm{~m}$ during three consecutive years, 1969-1971 [Lazier, 1980], whereas it penetrated to $2300 \mathrm{~m}$ in the winter of 1992 [Lazier, 1995] and $1750 \mathrm{~m}$ in 1995 [Lilly et al., 1999].

[4] We take advantage of this natural variability to force a model of ecosystem and biogeochemical flows to investigate the sensitivity of the downward export of biogenic carbon to changes in winter convection and surface water temperature. This modeling analysis was conducted with physical data collected at Ocean Station BRAVO in the central Labrador Sea $\left(56^{\circ} 30^{\prime} \mathrm{N}, 52^{\circ} 30^{\prime} \mathrm{W}\right)$ during warm (1966-1973) and cold (1991-1995) periods. The simulations were verified against biological/chemical data collected over both periods. The detailed methodology, the relative importance of various biogenic carbon export fluxes, and their stoichiometric characteristics are presented in a related paper [Tian et al., 2003]. We focus here on the interannual and interdecadal variations in particle sinking flux and DOC detrainment and their sensitivity to changes in ocean climate.

\section{Methods}

\subsection{General Structure of the Model}

[5] The structure, parameterization and parameter values of the model have been described in detail in previous papers [Tian et al., 2000, 2001]. The model consists of ten state variables and explicitly integrates the microbial food web (bacteria, small, i.e. $<5 \mu \mathrm{m}$ phytoplankton, microzooplankton, dissolved organic matter (DOM) and suspended detritus) with the mesoplankton food web (large, i.e. $>5 \mu \mathrm{m}$ phytoplankton, mesozooplankton $>200 \mu \mathrm{m}$ and large sinking particles). The growth rates of both large and small phytoplankton are controlled by photosynthetically active radiation $(P A R)$, temperature and the concentration of inorganic nitrogenous nutrients (i.e. nitrate and ammonium), and phytoplankton losses are controlled by grazing, exudation of DOM, senescence, aggregation and sinking. Carbon export fluxes include both the sinking of particles as well as the export of dissolved organic carbon by convective mixing.

\subsection{DOM-Bacteria Interactions}

[6] Parameterization of bacterial uptake of DOM was based on work by Bissett et al. [1999]. The C:N ratio has been suggested as an indicator of the freshness and bioavailability of particulate organic matter [Newton et al., 1994; Loh and Bauer, 2000; Nodder and Northcote, 2001]. Accordingly, we linked the half saturation concentration $\left(H_{D O M}\right)$ to the C:N ratio to capture the bioavailability of labile, semi-labile and refractory DOM through an exponential relationship,

$$
H_{D O M}=H_{D O M 0} e^{\alpha_{H C N} C: N_{D O M}},
$$

where $H_{D O M 0}$ is a constant representing the Y-intercept of this exponential function $\left(0.1 \mathrm{mmol} \mathrm{C} \mathrm{m}^{-3}\right)$ and $\alpha_{H C N}$ is the exponential slope between the half saturation concentration and the C:N ratio of DOM (0.3, dimensionless). These parameter values were determined to provide reasonable end-points to the bioavailability of DOM as a function of the molar C:N ratio. At a molar C:N of 6.6 and with these parameter choices, equation (1) results in a half-saturation constant of $0.7 \mathrm{mmol} \mathrm{C} \mathrm{m}{ }^{-3}$, implying very fast bacterial utilization of the DOM. At a molar $\mathrm{C}: \mathrm{N}$ ratio of 27.5 , equation (1) gives a half-saturation concentration of $383 \mathrm{mmol} \mathrm{C} \mathrm{m}^{-3}$, which inhibits the uptake of DOM in the model. This $\mathrm{C}: \mathrm{N}$ ratio is typical of the refractory DOM observed to accumulate in deep water across decadal timescales at HOTS (Hawaii Ocean Time series Station [Church et al., 2002]).

[7] In the model, DOM is produced from phytoplankton exudation and zooplankton feeding losses (e.g., sloppy feeding and excretion). The DOM released from phytoplankton was assumed to have the same $\mathrm{C}: \mathrm{N}$ ratio as their originating biological pools (i.e., Redfield ratio [Ogawa et al., 1999; Carlson et al., 2000]). This can be a simplification because DOC and DON may be uncoupled during their release [Søndergaard et al., 2000]. Owing to the high bioreactivity of the newly released dissolved organic matter which is rapidly recycled in surface waters, these short-term variations in the $\mathrm{C}: \mathrm{N}$ ratio have little impact on the $\mathrm{C}: \mathrm{N}$ ratios of exported materials [Bury et al., 2001; Kahler and Koeve, 2001]. On seasonal and annual timescales and particularly with respect to vertical fluxes, our assumption is plausible.

[8] The C:N in DOM from zooplankton feeding losses depends on the $\mathrm{C}: \mathrm{N}$ ratio of prey, the $\mathrm{C}: \mathrm{N}$ ratio of predator, and the gross growth efficiency of zooplankton. On the basis of nitrogen balance, the C:N ratio of DOM from zooplankton feeding losses is computed as the inverse of $\mathrm{N}: \mathrm{C}$ ratio,

$$
(N: C)_{\text {loss }}=\left(\frac{(N: C)_{\text {prey }}-e(N: C)_{\text {pred }}}{1-e}\right),
$$

where $e$ is the carbon gross growth efficiency of meso- or microzooplankton and the subscripts indicate the $\mathrm{N}: \mathrm{C}$ ratios of feeding losses, prey and predators [Landry, 1993]. After formation, the $\mathrm{C}: \mathrm{N}$ ratio of DOM changes with time through selective remineralization by bacterial uptake and respiration [Legendre and Rassoulzadegan, 1995; Hoch and Kirchman, 1995; Benner et al., 1997; Libby and Wheeler, 1997]. On the basis of work by Bissett et al. [1999], when DON can satisfy the $\mathrm{N}$ demand of bacteria (deduced from the $\mathrm{C}: \mathrm{N}$ ratio of $\mathrm{DOM}$ ), the ratio of bacterial remineralization between DOC and DON is the same as the bacterial $\mathrm{C}: \mathrm{N}$ ratio (5.1 in moles, lower than that of DOM). As relatively more DON is remineralized than DOC, the C:N of DOM increases and bioavailability decreases as a function of bacterial activity and time. When DON cannot satisfy the $\mathrm{N}$ demand of bacteria, $\mathrm{NH}_{4}^{+}$is taken up and the ratio of bacterial remineralization between DOC and DON is between the C:N of bacteria and that of DOM, which still leads to a reduction in bio-availability, albeit more slowly.

\subsection{Physical Forcing}

[9] The biological model was driven by hourly solar radiation (computed [Tian et al., 2000]), by surface water 


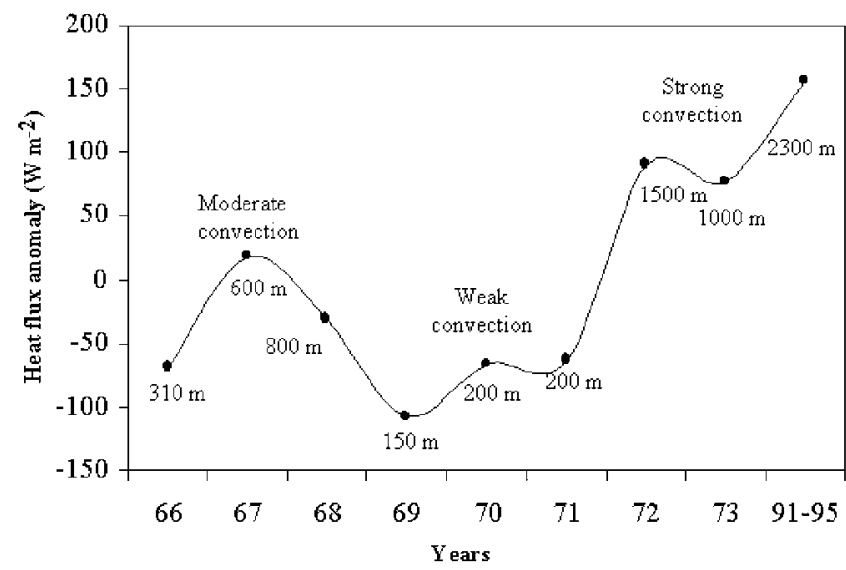

Figure 1. Winter (January through March) sea-air net heat flux anomaly (positive from the ocean to the atmosphere) from 1966 through 1973 and the average between 1990 and 1995. Intermediate heat flux anomaly from 1966 to 1968 and in 1973 ( -70 to $75 \mathrm{~W})$ corresponds to moderate convection (mixed layer depth MLD $=310-1000 \mathrm{~m}$ ). Low heat flux anomaly from 1969 to $1971(-108$ to $-63 \mathrm{~W})$ generated weak convection (MLD $=150-200 \mathrm{~m})$ and high heat flux anomaly in 1972 and during the early 1990s (90 to $156 \mathrm{~W}$ ) created strong convection (MLD $=1500-2300 \mathrm{~m}$ ). Net heat flux was downloaded from http://ingrid.ldgo. columbia.edu, and the mixed layer depth was determined from CTD profiles [Shuhy, 1969, 1974].

temperature (field measurements), and by vertical mixing. The vertical mixing coefficient $(K(\mathrm{z}))$ for the surface mixed layer was computed by a diagnostic model,

$$
K(z)=\alpha(B h)^{1 / 3},
$$

where $\alpha$ is a constant, $B$ is the buoyancy flux at the sea surface, and $h$ is the surface mixed layer depth [Raach and Etling, 1998; Steffen and D'Asaro, 2002]. The surface mixed layer depth $h$ was defined as the depth over which temperature and salinity were essentially constant [Lazier, 1980]. By setting $\alpha$ to 1 , we were able to generate vertical mixing coefficients of $1700-2300 \mathrm{~m}^{2} \mathrm{~d}^{-1}$ during weakconvection periods and $4400-6600 \mathrm{~m}^{2} \mathrm{~d}^{-1}$ during strong convection periods which fall within the range of field observations (i.e., $2000-8000 \mathrm{~m}^{2} \mathrm{~d}^{-1}$ [Lilly et al., 1999]). The buoyancy flux at the sea surface was determined by

$$
B=\frac{g}{\rho_{s}} \frac{\partial \rho}{\partial t}=\frac{g \alpha}{\rho_{s}^{2} C_{p}} Q
$$

where $g$ is gravitational force $\left(9.8 \mathrm{~m} \mathrm{~s}^{-2}\right), \rho_{s}$ is surface water density, $\sigma$ is the thermal expansion coefficient of seawater $\left(-0.23 \mathrm{~kg} \mathrm{~m}^{-3}{ }^{\circ} \mathrm{C}^{-1}\right), C_{p}$ is the specific heat of seawater $\left(4.088 \times 10^{3} \mathrm{~J} \mathrm{~kg}^{-1}{ }^{\circ} \mathrm{C}^{-1}\right)$, and $Q$ is net heat flux at the sea surface (Figure 1). Because of the limited number of vertical profiles available over the early 1990s (i.e., 44, versus 776 profiles from 1966 to 1973 [Shuhy, 1969, 1974]), we constructed an "average" scenario of mixed layer depth and surface water temperature for the early 1990s. The buoyancy flux was calculated from mean, monthly, net heat fluxes at the sea surface for each simulated year (http://ingrid.ldgo.columbia.edu). This model only represents a first approximation to the level of vertical convection. However, we applied the model in a diagnostic mode with field CTD data that included the effects of salinity fluctuations, and the influence of horizontal advection and precipitation (i.e., incorporated in the determination of $h$ from temperature and salinity profiles).

\subsection{Simulation Verification With Field Observations}

[10] Vertical profiles of chlorophyll concentrations $(\mathrm{n}=11)$, mesozooplankton $(\mathrm{n}=3)$, nitrate $(\mathrm{n}=11)$, ammonium $(\mathrm{n}=2)$, bacteria $(\mathrm{n}=8)$, and DOC $(\mathrm{n}=2)$ and estimates of phytoplankton biomass based upon Continuous Plankton Recorder (CPR) data, were used to verify the biological model (Figure 2). Profiles of chlorophyll, nitrate, bacteria, and DOC were collected during the late 1990s (W. K. W. Li, personal communication, 2002). Ammonium and CPR data were extracted from the literature [Maclaren Atlantic Ltd., 1976; Irwin et al., 1986, 1989, 1990; Myers et al., 1994]. The 2 DOC profiles from Station Bravo (Figures $2 \mathrm{i}$ and $2 \mathrm{j}$; P. Kepkay, personal communication) allowed us only to verify the shape and magnitude of the simulated DOC concentration profile.

[11] The seasonal cycle of DOC vertical distribution was also compared to 11 DOC profiles collected at Station DYFAMED located in the Western Mediterranean (Figure 3 [Copin-Montegut and Avril, 1993]). The DYFAMED data set is the only time series data of DOC available for deepwater formation regions. Given the diversity of the biological data, collected from the late 1960s (e.g., CPR data) to the late 1990s (e.g., DOC and bacteria data), the constructed seasonal pattern in biological dynamics only represent an averaged scenario over a multiyear timescale. However, the model was forced by physical data specific to each period. Our primary goal here is to analyze the sensitivity of biogenic carbon export to changes in ocean-climate conditions.

[12] The model broadly reproduced both the observed seasonal cycle of phytoplankton biomass (Figure 2a), and the vertical structures of bacteria (Figures $2 b-2 h$ ) and DOC (Figures $2 \mathrm{i}$ and $2 \mathrm{j}$ ). The bloom lasted from May until July with the maximum biomass of $19 \mathrm{~g} \mathrm{C} \mathrm{m}^{-2}$ during late June (equivalent to $380 \mathrm{mg} \mathrm{Chl} \mathrm{m}^{-2}$; Figure 2a), Apparently, the model overestimated bacterial biomass in deep layers. Owing to low temperature year round in deep waters, the model generated low bacterial activity in deep layers so that the overestimated bacterial biomass unlikely resulted in important bias in DOC distribution. Although the observed distribution of DOC in the water column appears more complex than that simulated, the general patterns of seasonal cycles in DOC distribution are comparable between observations and simulations (Figure 3). Observations made in the Mediterranean Sea and our simulations both show DOC production and an accumulation during spring and summer, a reduction through bacterial remineralization in autumn and the export of the residual DOC during winter convection. In the central Labrador Sea region, DOC concentration in the top $10 \mathrm{~m}$ generally varies between 48 

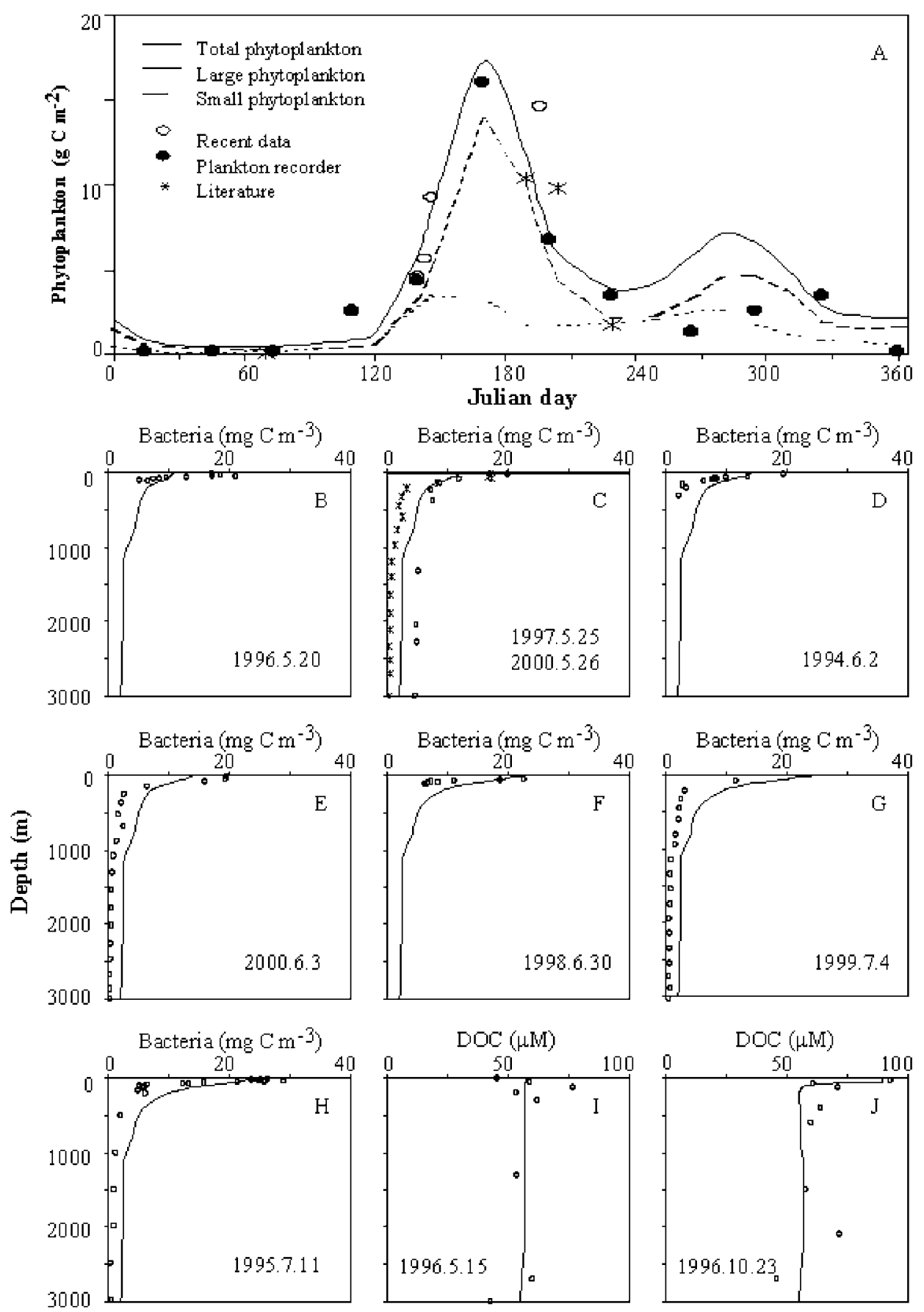

Figure 2. (a) Measured (symbols) and simulated (lines) phytoplankton biomass integrated over the euphotic zone. Simulations are total, large $(>5 \mu \mathrm{m})$ and small $(<5 \mu \mathrm{m})$ phytoplankton biomass, and data are total phytoplankton biomass from recent (1990-1998) cruises (open circles; W. K. W. Li, personal communication, 2002), Continuous Plankton Recorder (CPR; points) [Myers et al., 1994], and previous studies (stars [Maclaren Atlantic Ltd., 1976; Irwin et al., 1986, 1989, 1990]. CPR data were used to assess the relative abundance of phytoplankton; biomass was estimated by a correlation between values of the CPR color index and the chlorophyll data collected during recent years; $(b-j)$ Examples of measured (open circles) and simulated (solid line) profiles of bacteria and DOC. Note that there are two measured profiles in Figure 2c from 1997 (stars) and 2000 (circles). 

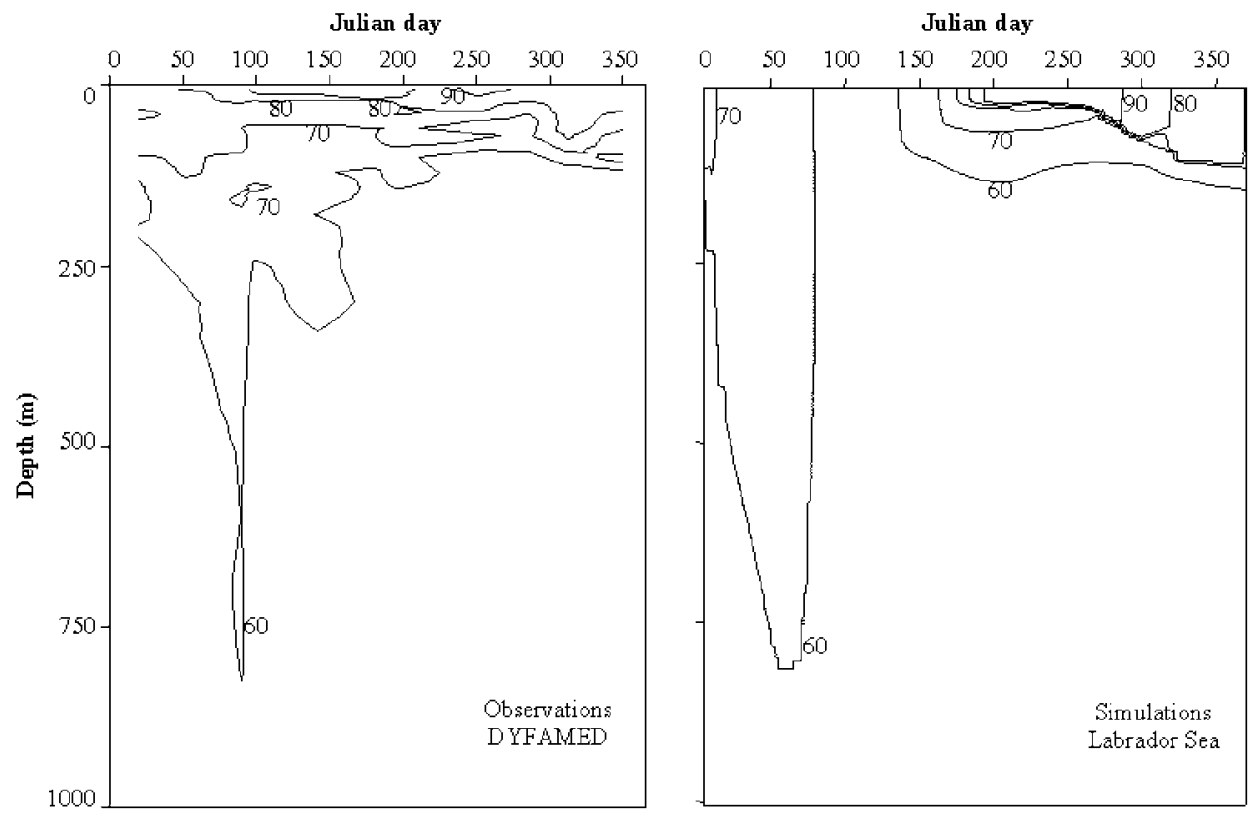

Figure 3. Seasonal dynamics of DOC observed in 1992 at the DYFAMED station in the western Mediterranean Sea [Copin-Montegut and Avril, 1993] and simulated for the early 1990s at station BRAVO in the central Labrador Sea. Both show DOC production and accumulation during the summer productive season, decrease in DOC concentration in late fall, and export during winter convection.

and $62 \mu \mathrm{M}$ during May and rises to between 65 and $90 \mu \mathrm{M}$ in October (P. Kepkay, personal communication, 2002). This matches relatively well with the DOC accumulation simulated by the model over the same period (Figure 3). Recent measurements from sediment trap deployed at the Bravo Station in 2001 resulted in a particle sinking flux of $2 \mathrm{~g} \mathrm{C} \mathrm{m}^{-2} \mathrm{yr}^{-1}$ at $1000 \mathrm{~m}$ (G. Harrison, personal communication, 2003), comparable with the simulated results ranging from 2.1 to $2.8 \mathrm{~g} \mathrm{C} \mathrm{m}^{-2} \mathrm{yr}^{-1}$ (Table 1). Moreover, the model has been thoroughly tested using time series data from high-latitude environments [Tian et al., 2000, 2001]. Previous studies have shown that the model accurately reproduces seasonal changes in biomass, food web structure and export fluxes.

\subsection{Multiyear Simulations and Sensitivity Analysis}

[13] After verifying the 1990s run with the available biological data (i.e., the standard run), we ran the model for several annual cycles using the climate forcing data from 1966. During these runs, the final value of each of the ten state variables at the end of each of the annual simulation (i.e., the concentrations on day 365) were used as initial concentration (i.e., concentrations on day 1) of that state variable at the beginning of the subsequent annual cycle. This initialization procedure was repeated until a stationary annual cycle was attained. This was done to ensure that interannual variability in the simulated output was not due to numerical instability in the model. Finally, the model was run continuously for the period from 1966 to 1973 with the climate forcing data specific for each of the 8 years. The model outputs are summarized into integrated annual values (Table 1) and correlated with the mixed-layer depth and
NAO index through principal component analysis (see Figure 5 in section 3 )

[14] The vertical export of DOC can be controlled by both biological (i.e., microbial utilization) and physical (i.e., convective mixing) factors and the interactions between them. We then conducted sensitivity analyses to assess the relative importance of temperature and convective mixing to microbial activity and the impact of the microbial food web on POC and DOC export. To examine the relative importance of temperature and mixing, we sequentially substituted the higher temperatures and shallow convective mixing regime observed in 1969 into the standard run (i.e., a period of low temperatures and deep convection). To examine the impact of changes in microbial food web activity on biogenic carbon cycling and export, we increased bacterial growth rate by $25 \%$ in the standard run while holding all other parameters and forcings constant. Bacterial utilization of DOC was also removed from the model to determine the importance of winter convection in DOC export without interference with microbial activities (Table 1).

\section{Results}

[15] Simulated primary production ranges from $117 \mathrm{~g} \mathrm{C}$ $\mathrm{m}^{-2} \mathrm{yr}^{-1}$ to $166 \mathrm{~g} \mathrm{C} \mathrm{m}^{-2} \mathrm{yr}^{-1}$ across all simulations (Table 1). This range is similar to remote sensing estimates for this region (i.e., $100-140 \mathrm{~g} \mathrm{C} \mathrm{m}^{-2} \mathrm{yr}^{-1}$ [Antoine et al., 1996; Behrenfeld and Falkowski, 1997]). The simulated annual $f$-ratio, which represents the proportion of primary production supported by nitrate, ranges from 0.48 to 0.60 across all simulations. These simulated values are slightly higher than the estimate of 0.47 based upon nutrient and 
Table 1. Range (Minimum-Maximum) of Simulated Biological Production for Different Food Web Components in the Euphotic Zone and the Biogenic Carbon Export $\left(\mathrm{g} \mathrm{C} \mathrm{m}^{-2} \mathrm{yr}^{-1}\right)$ in the Water Column Under Different Winter Convection Regimes

\begin{tabular}{|c|c|c|c|c|c|c|c|c|c|}
\hline \multirow[b]{3}{*}{ Period, years } & \multirow{2}{*}{$\begin{array}{c}\text { Strong } \\
\text { Convection } \\
\text { (cold) } \\
\end{array}$} & \multirow{2}{*}{$\begin{array}{c}\text { Moderate } \\
\text { Convection } \\
\text { (intermediate) }\end{array}$} & \multirow{2}{*}{$\begin{array}{c}\text { Weak } \\
\text { Convection } \\
\text { (warm) }\end{array}$} & & \multicolumn{5}{|c|}{ Sensitivity Analysis Based on 1990s Run } \\
\hline & & & & & (a) & (b) & (c) & (d) & (e) \\
\hline & $\begin{array}{c}1972, \\
1990-1995 \\
\end{array}$ & $\begin{array}{c}1966-1968, \\
1973 \\
\end{array}$ & $1969-1971$ & $\mathrm{CV}$ & $\begin{array}{c}1969 \\
\text { Temperature } \\
\end{array}$ & $\begin{array}{c}1969 \\
\text { mixing }\end{array}$ & $\mu_{b}+25 \%$ & $\mu_{b}=0$ & $\begin{array}{c}1969 \text { mixing; } \\
\mu_{\mathrm{b}}=0\end{array}$ \\
\hline Winter convection Depth, m & $1500-2300$ & $300-1000$ & $150-200$ & 92 & 2300 & 150 & 2300 & 2300 & 150 \\
\hline Convection Coefficient, $\mathrm{m}^{2} \mathrm{~d}^{-1}$ & $4400-6600$ & $2400-4400$ & $1700-2300$ & 51 & 6600 & 1700 & 6600 & 6600 & 1700 \\
\hline NAO Index & $0.3-5.0$ & $-1.0-2.5$ & $-1.0-4.9$ & - & 3 & 3 & 3 & 3 & 3 \\
\hline \multicolumn{10}{|c|}{ Euphotic Zne } \\
\hline Large cell production & $64-69$ & $72-78$ & $57-67$ & 9 & $+6 \%$ & $-1 \%$ & $-18 \%$ & $+4 \%$ & $+16 \%$ \\
\hline Small cell production & $53-58$ & $62-87$ & $66-99$ & 21 & $+5 \%$ & $+65 \%$ & $+52 \%$ & $-56 \%$ & $-51 \%$ \\
\hline Bacteria production & $19-20$ & $22-27$ & $23-29$ & 14 & $+6 \%$ & $+41 \%$ & $+58 \%$ & $-100 \%$ & $-100 \%$ \\
\hline$f$-ratio of large cells & $0.79-0.83$ & $0.74-0.78$ & $0.76-0.78$ & 7 & $-5 \%$ & $+3 \%$ & $+1 \%$ & $+22 \%$ & $+20 \%$ \\
\hline$f$-ratio of small cells & $0.33-0.35$ & $0.31-0.33$ & $0.28-0.30$ & 6 & $-5 \%$ & $-9 \%$ & $-20 \%$ & $+56 \%$ & $+54 \%$ \\
\hline Sinking flux & $22-24$ & $23-27$ & $24-29$ & 10 & $+2 \%$ & $+26 \%$ & $+11 \%$ & $-4 \%$ & $+11 \%$ \\
\hline DOC export & $28-43$ & $26-33$ & $20-28$ & 27 & $+3 \%$ & $-13 \%$ & $-71 \%$ & $+26 \%$ & $+24 \%$ \\
\hline $\mathrm{C}: \mathrm{N}$ in $\mathrm{DOM}$ export & $11-12$ & $12-13$ & $13-14$ & 7 & $+2 \%$ & $+8 \%$ & $+10 \%$ & $-19 \%$ & $-26 \%$ \\
\hline C:N in POM fluxes & 7.0 & $6.9-7.0$ & $6.8-6.9$ & 1 & $0 \%$ & $-2 \%$ & $-1 \%$ & $+1 \%$ & $+1 \%$ \\
\hline $\mathrm{NO}_{3}^{+}$flux $(\mathrm{mol} \mathrm{N})$ & $0.67-0.73$ & $0.69-0.73$ & $0.60-0.74$ & 9 & $+2 \%$ & $-15 \%$ & $-18 \%$ & $+8 \%$ & $+7 \%$ \\
\hline \multicolumn{10}{|c|}{ Fluxes at $200 \mathrm{~m}$} \\
\hline Sinking flux & $12.5-14.5$ & $13.7-16.3$ & $14.7-17.2$ & 9 & $+1 \%$ & $+25 \%$ & $+5 \%$ & $+3 \%$ & $+16 \%$ \\
\hline DOC flux & $19-30$ & $13-20$ & $5-7$ & 55 & $+4 \%$ & $-64 \%$ & $-81 \%$ & $+35 \%$ & $-40 \%$ \\
\hline $\mathrm{C}: \mathrm{N}$ in DOM export & $12-14$ & $13-14$ & $14-16$ & 9 & $-2 \%$ & $+6 \%$ & $+4 \%$ & $-8 \%$ & $-16 \%$ \\
\hline $\mathrm{C}: \mathrm{N}$ in POM export & 7.1 & 7.1 & 6.9 & 1.3 & $+1 \%$ & $-3 \%$ & $-2 \%$ & $+1 \%$ & $+1 \%$ \\
\hline $\mathrm{NO}_{3}^{+}$flux $(\mathrm{mol} \mathrm{N})$ & $0.39-0.70$ & $0.34-0.53$ & $0.12-0.15$ & 55 & $+1 \%$ & $-61 \%$ & $-27 \%$ & $+6 \%$ & $-61 \%$ \\
\hline \multicolumn{10}{|c|}{ Fluxes at $500 \mathrm{~m}$} \\
\hline Sinking flux & $4.4-4.8$ & $4.8-4.9$ & $4.3-4.8$ & 6 & $+3 \%$ & $+6 \%$ & $-4 \%$ & $+6 \%$ & $+17 \%$ \\
\hline DOC export & $18.0-24$ & $6.9-18.0$ & $5.4-6.0$ & 111 & $+10 \%$ & $-99 \%$ & $-99 \%$ & $+46 \%$ & $-98 \%$ \\
\hline $\mathrm{C}: \mathrm{N}$ in DOM export & $12.0-15$ & $13.2-14.3$ & $14.3-16.2$ & 9 & $-5 \%$ & $+5 \%$ & $+5 \%$ & $-6 \%$ & $-91 \%$ \\
\hline $\mathrm{C}: \mathrm{N}$ in POM fluxes & 8.3 & $8.2-8.3$ & $7.6-7.9$ & 3 & $+3 \%$ & $-5 \%$ & $-4 \%$ & $+6 \%$ & $+5 \%$ \\
\hline $\mathrm{NO}_{3}^{+}$flux $(\mathrm{mol} \mathrm{N})$ & $0.16-0.24$ & $0.08-0.25$ & 0.0 & 99 & $+1 \%$ & $-100 \%$ & $-37 \%$ & $+5 \%$ & $-98 \%$ \\
\hline \multicolumn{10}{|c|}{ Fluxes at $1000 \mathrm{~m}$} \\
\hline Sinking flux & $2.7-2.8$ & $2.6-2.8$ & $2.1-2.4$ & 6 & $+3 \%$ & $+6 \%$ & $-4 \%$ & $+15 \%$ & $+16 \%$ \\
\hline DOC flux & $0.2-2.8$ & $0-0.8$ & 0 & 111 & $+10 \%$ & $-99 \%$ & $-99 \%$ & $+300 \%$ & $-100 \%$ \\
\hline $\mathrm{C}: \mathrm{N}$ in DOM export & $15-17$ & $17-24$ & $20-24$ & 17 & $-6 \%$ & $+5 \%$ & $+21 \%$ & $-10 \%$ & 0 \\
\hline $\mathrm{C}: \mathrm{N}$ in POM fluxes & $9.3-10.3$ & $10.0-10.3$ & $8.9-9.9$ & 5 & $+3 \%$ & $+5 \%$ & $-0 \%$ & $+5 \%$ & $+8 \%$ \\
\hline $\mathrm{NO}_{3}^{+}$flux (mol N) & $0.03-0.1$ & $0.01-0.05$ & 0.01 & 124 & $-88 \%$ & $-99 \%$ & $-41 \%$ & $+8 \%$ & $-98 \%$ \\
\hline
\end{tabular}

Winter convection depth was defined as the depth over which temperature and salinity were constant. Results of sensitivity analyses on the $1990 \mathrm{~s}$ standard run are also shown as percent change from value in standard run. For (a) and (b), we substituted the convection and temperature forcing from 1969 (weak convection) into the 1990s run (strong convection) (see text for details). For (c), we increased bacterial growth rate at $0{ }^{\circ} \mathrm{C}\left(\mu_{\mathrm{b}}\right)$ by $25 \%$ (from 0.07 to $0.0875 \mathrm{~d}^{-1}$ ). For (d) and (e), we removed the bacterial utilization of DOC, but with strong (d) and weak (e) winter convection, respectively; CV is the Coefficient of Variation across all convection regimes. -: No value.

dissolved oxygen data from the region [Louanchi and Najjar, 2001]. The simulated seasonal cycles of phytoplankton biomass are similar under weak and strong convection regimes (Figure 4). However, the peak phytoplankton biomass during the spring bloom is slightly higher and occurs $\sim 20$ days later under strong winter convection (Figure 4c). The simulated maximum phytoplankton biomass ranges from 17 to $19 \mathrm{~g} \mathrm{C} \mathrm{m}^{-2}$ under strong winter convection, whereas it ranges from 13 to $14 \mathrm{~g} \mathrm{C} \mathrm{m}^{-2}$ under weak winter convection.

[16] Our simulations suggest that the annual production of microbial food web is more sensitive to ocean climate than that of the mesoplankton. For example, the annual production of small phytoplankton ranges from 53 to $58 \mathrm{~g} \mathrm{C} \mathrm{m}^{-2}$ $\mathrm{yr}^{-1}$ under strong winter convection, whereas it ranges from 66 to $99 \mathrm{~g} \mathrm{C} \mathrm{m}^{-2} \mathrm{yr}^{-1}$ under weak winter convection (Table 1). Also, the mean annual production of bacteria is
$33 \%$ higher on average under weak winter convection than under strong winter convection. In contrast, large cell production is relatively stable, with a coefficient of variation (C.V.) of $9 \%$ over all simulations, compared to small cell production with a C.V. of $21 \%$ and bacterial production with a CV of $14 \%$.

[17] Similarly, DOC export is more variable than particle sinking flux (Table 1). Under strong winter convection, DOC export from the euphotic zone is $57 \%$ higher than particle sinking flux whereas the two modes of export are of comparable magnitude under weak convection. The simulated C:N ratio of exported DOM varies from 11 to 14 across all convection regimes while that of sinking particles is nearly constant at $6.8-7.0$. The convection-driven variability in DOC export increases with depth, with the C.V. increasing from $27 \%$ at the bottom of the euphotic zone to over $100 \%$ in deep layers, whereas the C.V. of particle 

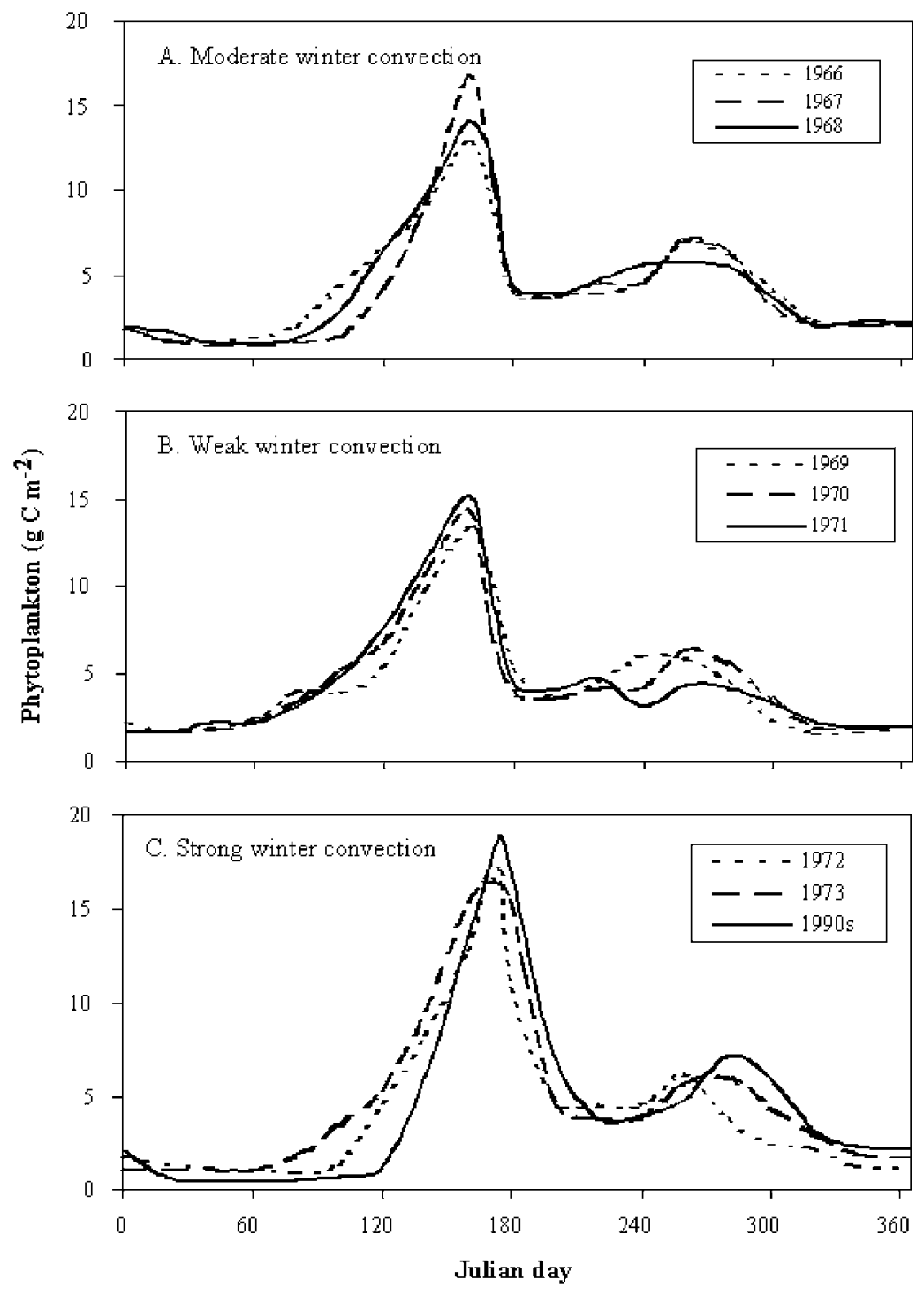

Figure 4. Simulated total phytoplankton biomass in the euphotic zone from 1966 through 1973 and in the early 1990s to show the variability in the magnitude and timing of phytoplankton seasonal cycles in response to convection scenarios.

sinking flux remains $<6 \%$ from the surface to deeper layers. At $200 \mathrm{~m}$ depth, the total biogenic carbon export (particle sinking flux + DOC export) is higher by $16 \mathrm{~g} \mathrm{C} \mathrm{m}^{-2} \mathrm{yr}^{-1}$ under strong convection than under weak convection, representing $52 \%$ of the average over all the simulations. Similarly, at $500 \mathrm{~m}$ depth, the total biogenic carbon export is $15 \mathrm{~g} \mathrm{C} \mathrm{m}^{-2} \mathrm{yr}^{-1}$ higher under strong than under weak convection, amounting to $90 \%$ of the average. These large variations in total biogenic carbon export are essentially due to the response of DOC export to ocean climate conditions.

[18] A principal component analysis of model output indicates that microbial production (small phytoplankton, microzooplankton, and bacteria) is inversely related to the mixed-layer depth and the winter NAO index on the first principal component axis, which accounts for $58 \%$ of the variance in the data (Figure 5). Large phytoplankton exhibits less sensitivity to the mixed-layer depth and the winter
NAO index and is moderately independent from variations in the microbial food web. Mesozooplankton and sinking flux are located between large phytoplankton and the microbial food web, implying that they are sustained by both large cells and microbial organisms. DOC export shows a positive relationship with the mixed-layer depth and an inverse relationship with the microbial food web.

[19] Sensitivity analysis shows that simulated variations in microbial food web activity are primarily associated with changes in the convection regime, and that altering temperature over the natural range (i.e., $1^{\circ} \mathrm{C}$ higher in 1969 than in the early 1990s) has relatively little impact on euphotic zone carbon cycling or biogenic carbon export (Table 1, sensitivity analyses "a" and " $b$ "). When the bacterial growth rate is increased by $25 \%$ in the model, particulate biogenic carbon export changes by $\leq 5 \%$, whereas DOC export declines by $81 \%$ at $200 \mathrm{~m}$ and $\sim 99 \%$ at $500 \mathrm{~m}$ (Table 1 , 


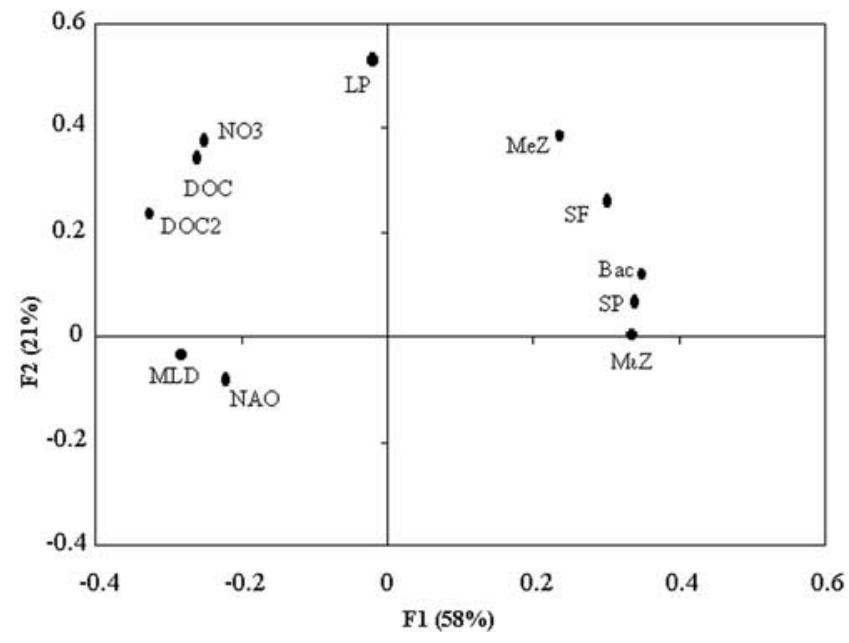

Figure 5. Principal component analysis of ocean climate parameters, biological productions, and fluxes of biogenic carbon export across the bottom of the euphotic zone. Factor 1 (F1) represents 58\% and factor 2 (F2) accounts for $21 \%$ of the total variance, respectively. Bac: bacterial production; DOC: DOC export from the euphotic zone; DOC2: DOC export flux at $200 \mathrm{~m}$; LP: large cell production; MeZ: mesozooplankton production; MiZ: microzooplankton production; MLD: winter mixed layer depth; NAO: North Atlantic Oscillation Index; $\mathrm{NO}_{3}^{+}$: nitrate supply to the euphotic zone; SF: sinking flux across the bottom of the euphotic zone; SP: small cell production.

sensitivity analysis (c)). The $25 \%$ increase in growth rate results in a $58 \%$ increase in bacterial production (Table 1), which leads to the consumption of more DOC in the euphotic zone and a smaller pool of DOC at the end of the growing season and decreased DOC export (Figure 6).

[20] When bacterial consumption of DOM is removed from the model (Table 1, sensitivity analyses "d" and "e"), small cell production is decreased and the corresponding $f$-ratio is increased by over $50 \%$ under both strong (sensitivity analysis "d") and weak winter convection (sensitivity analysis "e"). DOC export from the euphotic zone is increased by a similar magnitude relative to the standard run under both convection regimes, by $26 \%$ under strong winter convection, and by $24 \%$ under weak winter convection. Thus the large differences in convective activity alone lead to only a small $8 \%$ change in DOC export between strong and weak convection regime. The DOC export from the euphotic zone appears thus to be controlled by the bacterial consumption. Changes in large cell production $(<16 \%)$ and particle sinking flux $(<11 \%)$ are much less than those in small cell production and DOC export when bacterial consumption of DOM is removed from the model.

[21] However, the export of biogenic carbon export to deep layers shows different responses to microbial activities and winter convection compared to the export from the euphotic zone. At $200 \mathrm{~m}$ depth, for example, the DOC export increases by $35 \%$ under strong convection but decreases by $40 \%$ under weak convection when the bacte- rial consumption of DOM is removed from the model. At $1000 \mathrm{~m}$ depth, the changes in DOC export flux reach $+300 \%$ and $-100 \%$ under the two different convection regimes, respectively. The model thus suggests that while the DOC export from the euphotic zone is regulated by bacterial consumption, the transport of DOC to deep waters is controlled by winter convection strength.

\section{Discussion}

[22] Our model suggests that the relationship between ocean climate conditions and biogenic carbon export involves a series of complex interactions between physical and biological dynamics. The simulated results show that the mesoplankton food web and particle sinking fluxes are relatively stable between strong and weak winter convection in the central Labrador Sea, whereas the microbial food web and DOC export are much more sensitive to ocean climate conditions.

[23] Our simulations suggest that large cells depend primarily up on $\mathrm{NO}_{3}^{+}$uptake with an $f$-ratio ranging from 0.74 to 0.83 . The low sensitivity of large cell production and particle sinking flux to ocean climate results from the low interannual variability in $\mathrm{NO}_{3}^{+}$supply to the euphotic zone. Our model predicts that the nitrate supply to the euphotic zone is not linearly related to rates of vertical convection; rather it is a function of the rates of remineralization and nitrification in subsurface waters in the Labrador Sea. Nitrate generation from remineralization and nitrification in the 100 to $200 \mathrm{~m}$ and 100 to $500 \mathrm{~m}$ depth ranges, respectively, accounts for $51 \%$ and $74 \%$ of the nitrate supply to the euphotic zone on average across all simula-

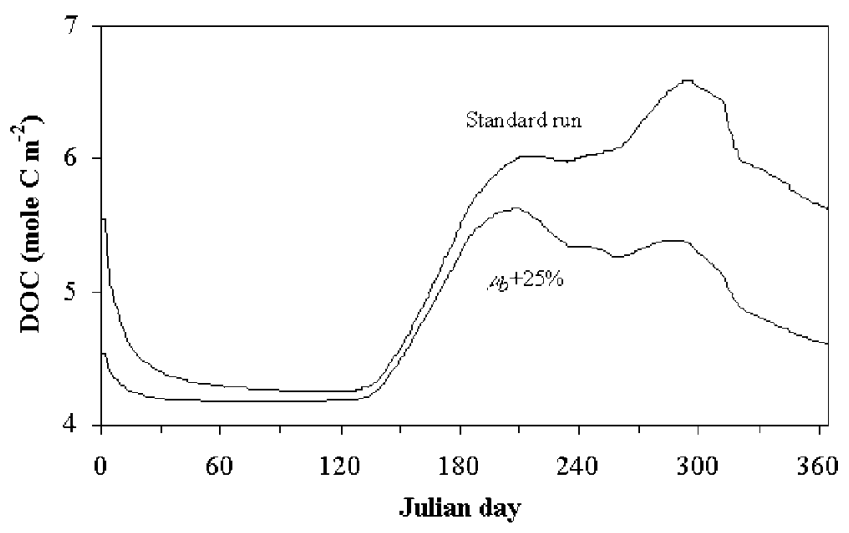

Figure 6. Sensitivity analysis to assess the influence of microbial activity on DOC dynamics. We increased the bacterial growth rate at $0{ }^{\circ} \mathrm{C}$ from $0.07 \mathrm{~d}^{-1}$ in the standard run to $0.0875 \mathrm{~d}^{-1}$ (i.e., the $\mu_{\mathrm{b}}+25 \%$ run) while holding all other model parameters and forcings constant (sensitivity analysis "c" in Table 1). The results show a reduction in DOC stocks by $65 \%$ (without the preformed refractory fraction) and in DOC export at $200 \mathrm{~m}$ by $81 \%$ compared to the standard run. The standard run represents the conditions under strong winter convection (typical of the early 1990s; see text). The minimum scale $\left(4\right.$ mole $\left.\mathrm{C} \mathrm{m}^{-2}\right)$ represents the refractory DOC. 


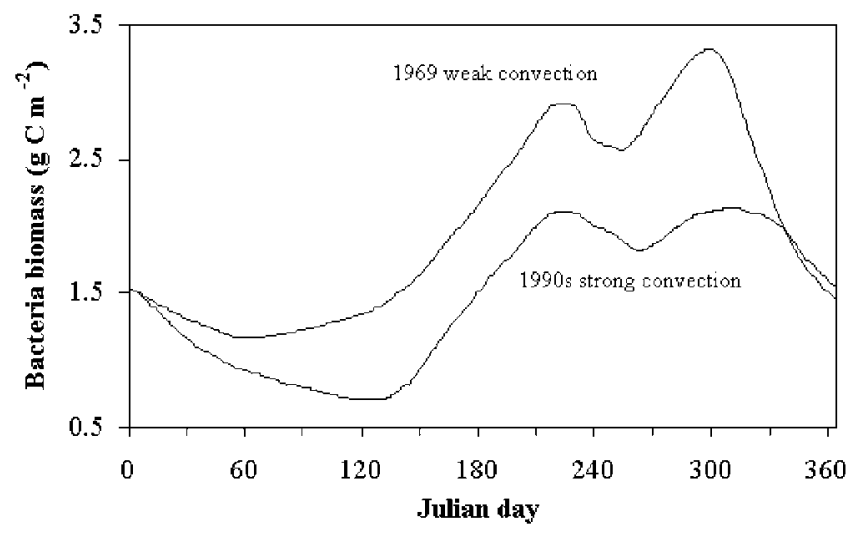

Figure 7. Sensitivity analysis to assess the influence of winter convection on bacterial biomass integrated over the euphotic zone. The vertical convection in the standard run was replaced by that of the 1969 run while holding all other model parameters and forcings constant (sensitivity analysis "d" in Table 1). The results show higher bacterial biomass in the euphotic zone under weak winter convection than under strong winter convection.

tions. These sub-euphotic zone processes of remineralization and nitrification buffer interannual variations in the upward flux of nitrate and the rate of new production.

[24] Vertical mixing also influences the time-averaged exposure of phytoplankton cells to light. Strong vertical mixing can bring more nutrients from deep water into the euphotic zone, thus enhancing primary production, and also reduces the average irradiance that phytoplankton are exposed to which can lead to a decrease in primary production by transporting cells below the critical depth. The relationship between mixing and primary production can be characterized by the ratio of the thickness of Sverdrup's critical layer $h_{c}$ and the mixed layer depth $h_{m}$ at the end of winter [Dutkiewicz et al., 2001]. In tropical and subtropical regions where $h_{c} / h_{m} \sim 1$, strong mixing enhances primary production by increasing the rate of nutrient supply. In subpolar regions where $h_{c} / h_{m} \ll 1$ in early spring, the sensitivity of primary production to the vertical convection of nutrients is much lower, and increased mixing can lead to lower phytoplankton abundance and primary production due to light limitation. This is indicated by the delayed start of the spring/summer phytoplankton bloom under strong convection (Figure 4).

[25] In contrast, the microbial food web is very sensitive to ocean climate in the model. With respect to bacteria, vertical convection does not affect any controlling parameters in the model (e.g., growth rate and respiration). Convection strength acts by redistributing biomass in the water column and by determining initial conditions at the end of the convection period, prior to the growth season. With all other physical forcings and biological controlling parameters held constant, strong winter convection results in a simulated bacterial biomass in the euphotic zone less than half than that under weak winter convection at the end of the convection season (Figure 7). Bacterial biomass continues to grow slowly through much of the winter season under weak convection, whereas it declines under strong convection. The post-convection dynamics in bacterial biomass in the euphotic zone are similar under both convection regimes. The lower mean annual bacterial biomass under strong convection results mostly from the lower starting point for growth between early spring and late autumn.

[26] In the model, DOM is mainly produced through phytoplankton exudation and remineralized through bacterial activity. Enhanced microbial activities under weak convection result in greater consumption of dissolved organic carbon in surface waters. Although DOC export to the deep ocean relies on deep convection, the microbial regulation on the quantity of DOC available for export is important in determining DOC export fluxes. A relatively small change in DOC export from the euphotic zone can result in relatively large variations in DOC export flux in the mesopelagic zone. In the sensitivity analysis " $d$ " in which bacterial consumption was removed from the model (Table 1), an increase in DOC export from the euphotic zone by $26 \%$ tripled DOC export at $1000 \mathrm{~m}$ depth under strong winter convection.

[27] Model outputs depend on the parameterization in the model. The DOC biogeochemical dynamics are certainly more complex than that a simulation model can parameterize. DOC can be released through phytoplankton exudation, cell lysis, zooplankton feeding losses, dissolution of fecal pellets, and other suspended particles [Noji et al., 1999; Urban-Rich, 1999; Doval et al., 2002]. Physical stress such as nutrient limitation, temperature, salinity, $\mathrm{pH}$, and light may lead to unhealthy cells and increasing DOC production [Kepkay, 2000]. In our model, DOC production is only linearly linked to phytoplankton biomass and zooplankton ingestion, without specific environmental forcing.

[28] The bioavailability of DOC and its temporal evolution remain poorly understood. The bulk DOC pool has been operationally separated into labile, semi-labile, and refractory portions [Carlson et al., 1994]. Labile DOC is highly bioavailable and turns over on timescales of hours to days. Semi-labile DOC is less bioavailable and turns over on seasonal and annual timescales. Refractory DOC is almost not bioavailable and turns over on millennial timescale. In our model, the $\mathrm{C}: \mathrm{N}$ ratio is used as an index of the bioavailability of DOM. According to the 1990s standard run, the overturning time of DOM ranges from 13 hours to 10 days in surface waters, $\sim 4$ months at $200 \mathrm{~m}$, and one and a half years at $1000 \mathrm{~m}$ (the overturning timescale of DOM was estimated by the quotient of DOM concentration over bacterial consumption). The refractory DOM in the model was simulated by a threshold below which DOM is not bioavailable.

[29] Labile DOC generally represents $<35 \%$, while refractory DOC accounts for $40-80 \%$ of the total DOC pool [Mopper et al., 1991; Kepkay, 2000]. According to the 1990s standard simulation, labile and semi-labile DOC together ranges from 3\% during the winter convection season to $51 \%$ during the summer-autumn productive season with an annual average of $24 \%$ of the total DOC pool in surface waters. It is not well known however, which part of the newly formed DOC is labile, semi-labile, or 
refractory. Some abiotic processes have been proposed in the formation of refractory DOC, such as aging, humification, reactions of newly formed with refractory DOC [Hatcher and Spiker, 1988; Keil and Kirchman, 1994; Amon and Benner, 1996] and condensation of exopolymer colloidal carbohydrates [Mopper and Kieber, 2000]. Bacteria also can produce refractory DOC [Tanoue et al., 1995; Suzuki et al., 1997; McCarthy et al., 1998] or selectively remineralize bioreactive compounds, leaving behind more refractory DOC [Benner et al., 1997; Thomas et al., 1999; Amon et al., 2001; Ogawa et al., 2001]. In our model, all the newly formed DOM was assumed to be bioavailable. The bioavailability of DOM evolves with bacterial selective remineralization which gradually increases the $\mathrm{C}: \mathrm{N}$ ratio of DOM. If a part of the newly formed DOM is refractory and/or an alternative mechanism transforms labile and semilabile DOM into refractory DOM, the bioavailability of DOM and the sensitivity of DOC export to bacterial growth can be overestimated in the model. Given the high sensitivity of DOC export to bacterial consumption, parameterization of the bioavailability of DOC in simulation models is thus of primary importance in order to accurately assess the biological pump and carbon sequestration in the ocean.

[30] Also, our simulated results suggest that a substantial part of the exported DOC from the euphotic zone is remineralized in subsurface waters. This intensive subeuphotic-zone remineralization can restrict the transfer efficiency from DOC export to deep carbon sequestration pools. Dissolved inorganic carbon (DIC) resulting from DOC remineralization can readily be advected upward to surface waters. Effective DOC export necessitates deep convection that occurs in deep-water formation region.

[31] Deep-water formation occurs in the Labrador, Weddell, Greenland, Norwegian, and Mediterranean Seas and in the Arctic and Antarctic Oceans [Pawlowicz et al., 1994]. In these areas, vertical DOC detrainment during deep-water formation can be a significant fraction of biogenic carbon export to depth [Hansell and Carlson, 1998]. DOC export accounts for $23-42 \%$ of total biogenic carbon export from the euphotic zone in the Sargasso Sea [Carlson et al., 1994; Hansell and Carlson, 1998] and is two-to-three-fold greater than particle sinking flux determined by sediment traps in the northwestern Mediterranean Sea [Copin-Montegut and Avril, 1993; Avril, 2002]. Moore et al. [2002] estimated that DOC detrainment can account for $30 \%$ of the global biogenic carbon export in the world oceans. Our simulations suggest that the sensitivity of biogenic carbon export reside in the strong interannual variability in DOC export. DOC is passively detrained into deep layers by vertical mixing so that the DOC export flux relies on the winter convection strength. Our model also pointed out that convection affects the development of the microbial food web which in turn regulates DOC export through its impact on DOC consumption and remineralization. This variability in the microbial utilization of DOC can potentially amplify the impact of variations in vertical mixing on DOC export to the deep ocean.

[32] Acknowledgments. This research was supported by research grants from the Natural Sciences and Engineering Research Council to A. A.V., D.D., and R.B.R. We particularly thank W.H.W. Li and
P. Kepkay who provided unpublished data for this study, and J. C. Marty and C. Migon for their critical revision during the preparation of this paper.

\section{References}

Amon, R. M., and R. Benner, Bacterial utilization of different size classes of dissolved organic matter, Limnol. Oceanogr., 41, 41-51, 1996.

Amon, R. M. W., H. P. Fitzar, and R. Benner, Linkages among the bioreactivity, chemical composition, and diagenetic state of marine dissolved organic matter, Limnol. Oceanogr., 46, 287-297, 2001.

Antoine, D., J. M. Andre, and A. Morel, Ocean primary production: 2. Estimation at global scale from satellite (coastal zone color scanner) chlorophyll, Global Biogeochem. Cycles, 10, 57-69, 1996.

Avril, B., DOC dynamics in the northwestern Mediterranean Sea (DYFAMED site), Deep Sea Res., Part II, 49, 2163-2182, 2002.

Behrenfeld, M. J., and P. G. Falkowski, Photosynthetic rates derived from satellite-based chlorophyll concentration, Limnol. Oceanogr., 42, 1-20, 1997.

Benner, R., B. Biddanda, B. Black, and M. McCarthy, Abundance, size distribution, and stable carbon and nitrogen isotopic composition of marine organic matter isolated by tangential-flow ultrafiltration, Mar. Chem., 57, 243-263, 1997.

Bissett, W. P., J. J. Walsh, D. A. Dieterle, and K. L. Carter, Carbon cycling in the upper waters of the Sargasso Sea: I. Numerical simulation of differential carbon and nitrogen fluxes, Deep Sea Res., Part I, 46, 205-269, 1999

Bury, S. J., P. W. Boyd, T. Preston, G. Savidge, and N. J. P. Owens, Sizefractionated primary production and nitrogen uptake during a North Atlantic phytoplankton bloom: Implications for carbon export estimates, Deep Sea Res., Part I, 48, 689-720, 2001

Carlson, C. A., H. W. Ducklow, and A. F. Michaels, Annual flux of dissolved organic carbon from the euphotic zone in the northwestern Sargasso Sea, Nature, 371, 405-408, 1994.

Carlson, C. A., D. A. Hansell, E. T. Peltzer, and W. O. Smith Jr., Stocks and dynamics of dissolved and particulate organic matter in the southern Ross Sea, Antarctica, Deep Sea Res., Part I, 47, 3201-3225, 2000.

Church, M. J., H. W. Ducklow, and D. M. Karl, Multiyear increases in dissolved organic matter inventories at Station ALOPHA in the North Pacific Gyre, Limnol. Oceanogr., 47, 1-10, 2002.

Copin-Montegut, G., and B. Avril, Vertical distribution and temporal variation of dissolved organic carbon in the North-Western Mediterranean Sea, Deep Sea Res., Part I, 40, 1963-1972, 1993.

Dickson, R. R., The local, regional, and global significance of exchanges through the Denmark Strait and Irminger Sea, in Natural Climate Variability on Decade-to-Century Time Scales, edited by D. G. Martinson, K. Bryan, and M. Ghil, pp. 305-317, Natl. Acad., Washington, DC, 1995.

Dickson, B., From the Labrador Sea to global change, Nature, 386, 649650, 1997.

Dickson, R. R., J. Lazier, J. Meincke, P. Rhines, and J. Swift, Long-term coordinated changes in the convective activity of the North Atlantic, Prog. Oceanogr., 38, 241-295, 1996.

Doval, M. D., X. A. Alvarez-Salgado, C. G. Castro, and F. F. Perez, Dissolved organic carbon distribution in the Bransfield and Gerlache Straits, Antarctica, Deep Sea Res., Part II, 49, 663-674, 2002.

Dutkiewicz, S., M. Follows, J. Marshall, and W. W. Gregg, Interannual variability of phytoplankton abundances in the North Atlantic, Deep Sea Res., Part II, 48, 2323-2344, 2001.

Gruder, N., C. D. Keeling, and N. R. Bates, Interannual variability in the North Atlantic Ocean carbon sink, Science, 298, 2374-2378, 2002.

Hansell, D. A., and C. A. Carlson, Deep-ocean gradients in the concentration of dissolved organic carbon, Nature, 395, 263-266, 1998.

Hatcher, P., and E. Spiker, Selective degradation of plant biomolecules, in Humic Substances and Their Role in the Environment, edited by F. Frimmel and R. Christman, pp. 59-74, John Wiley, Hoboken, N. J., 1988.

Hoch, M. P., and D. L. Kirchman, Ammonium uptake by heterotrophic bacteria in the Delaware Bay and adjacent coastal waters, Limnol. Oceanogr., 40, 886-897, 1995.

Hurell, J. W., Decadal trends in the North Atlantic Oscillations: Regional temperatures and precipitation, Science, 269, 676-679, 1995.

Irwin, B., C. Caverhill, P. Dickie, E. Horne, and T. Platt, Primary productivity on the Labrador Shelf during June and July 1984, Can. Rep. Fish Aquat. Sci., 577, 162 pp., 1986.

Irwin, B., C. Caverhill, D. Mossman, E. Horne, and T. Platt, Primary productivity on the Labrador Shelf during July 1985, Can. Rep. Fish. Aquat. Sci., 760, 115 pp., 1989.

Irwin, B., J. Anning, C. Caverhill, and T. Platt, Primary productivity on the Labrador Shelf and in the Strait of Belle Isle in May 1988, Can. Rep Fish. Aquat. Sci., 784, 131 pp., 1990. 
Kahler, P., and W. Koeve, Marine dissolved organic matter: Can its C:N ratio explain carbon overconsumption?, Deep Sea Res., Part I, 48, 4962, 2001.

Keil, R. G., and D. L. Kirchman, Abiotic transformation of labile protein to refractory protein in sea water, Mar. Chem., 45, 187-196, 1994.

Kepkay, P. E., Colloids and the ocean carbon cycle, in Handbook of Environmental Chemistry, edited by P. Wangersky, pp. 35-56, SpringerVerlag, New York, 2000.

Landry, M. R., Predicting excretion rates of microzooplankton from carbon metabolism and elemental ratios, Limnol. Oceanogr., 38, 468-472, 1993.

Lazier, J. R. N., Oceanographic conditions at Ocean Weather Ship Bravo, 1964-1974, Atmos. Ocean, 18, 227-238, 1980.

Lazier, J. R. N., The salinity decrease in the Labrador Sea over the past thirty years, in Natural Climate Variability on Decade-to-Century Time Scales, edited by D. G. Martison et al., pp. 295-304, Natl. Acad., Washington, DC, 1995

Legendre, L., and R. Rassoulzadegan, Plankton and nutrient dynamics in marine waters, Ophelia, 41, 153-172, 1995.

Le Quéré, C., J. C. Orr, P. Monfray, and O. Aumont, Interannual variability of the oceanic sink $\mathrm{CO}_{2}$ from 1979 through 1997, Global Biogeochem. Cycles, 14, 1247-1265, 2000.

Libby, P. S., and P. A. Wheeler, Particulate and dissolved organic nitrogen in the central and eastern equatorial Pacific, Deep Sea Res., Part I, 44 , 345-361, 1997.

Lilly, J. M., P. B. Rhines, M. Visbeck, R. Davis, J. R. N. Lazier, F. Schott, and D. Farmer, Observing deep convection in the Labrador Sea during winter 1994/95, J. Phys. Oceanogr., 29, 2065-2098, 1999.

Loh, A. N., and J. E. Bauer, Distribution, partitioning and fluxes of dissolved and particulate organic $\mathrm{C}, \mathrm{N}$, and $\mathrm{P}$ in the eastern North Pacific and Southern Oceans, Deep Sea Res., Part I, 47, 2287-2316, 2000.

Louanchi, F., and R. G. Najjar, Annual cycles of nutrients and oxygen in the upper layers of the North Atlantic Ocean, Deep Sea Res., Part II, 48, 2155-2171, 2001

Maclaren Atlantic Ltd., Preliminary Summary of Results of Imperial Oil Environmental Cruise Program, 57 pp., Halifax, N. S., Canada, 1976.

McCarthy, M. D., J. L. Hedges, and R. Benner, Major bacterial contribution to marine dissolved organic nitrogen, Science, 281, 231-234, 1998.

Moore, J. K., S. C. Doney, D. M. Glover, and I. Y. Fung, Iron cycling and nutrient-limitation patterns in surface waters of the World Ocean, Deep Sea Res., Part II, 49, 463-507, 2002.

Mopper, K., and D. J. Kieber, Marine photochemistry and its impact on carbon cycling, in The Effect of UV Radiation in the Marine Environment, edited by S. D. More, S. Demers, and M. Vernet, pp. 101-129, Cambridge Univ. Press, New York, 2000

Mopper, K., X. L. Zhou, R. J. Kieber, D. J. Kieber, R. J. Sikorski, and R. D. Jones, Photochemical degradation of dissolved organic carbon and its impact on the oceanic carbon cycle, Nature, 353, 60-62, 1991.

Myers, R. A., N. J. Barrowman, G. Mertz, J. Gambke, and H. G. Hunt, Analysis of continuous plankton recorder data in the northwest Atlantic, Can. Tech. Rep. Fish. Aquat. Sci., 16, 223 pp., 1994.

Newton, P. P., R. S. Lampitt, T. D. Jickells, P. King, and C. Boutle, Temporal and spatial variability of biogenic particle fluxes during the JGOFS northeast Atlantic process studies at $47^{\circ} \mathrm{N} 20^{\circ} \mathrm{W}$, Deep Sea Res., Part I, 41, 1617-1642, 1994.

Nodder, S. D., and L. C. Northcote, Episodic particulate fluxes at southern temperate mid-latitudes $\left(42-45^{\circ} \mathrm{S}\right)$ in the Subtropical Front region, east of New Zealand, Deep Sea Res., Part I, 48, 833-864, 2001.

Noji, T. T., F. Rey, L. A. Miller, K. Y. Borsheim, and J. Urban-Rich, Fate of biogenic carbon in the upper $200 \mathrm{~m}$ of the central Greenland Sea, Deep Sea Res., Part II, 46, 1497-1509, 1999.
Ogawa, H., R. Fukuda, and I. Koike, Vertical distribution of dissolved organic carbon and nitrogen in the Southern Ocean, Deep Sea Res., Part $I, 46,1809-1826,1999$.

Ogawa, H., Y. Amagai, I. Koike, and R. Benner, Production of refractory dissolved organic matter by bacteria, Science, 292, 917-920, 2001.

Pawlowicz, R. A., J. F. Lynch, W. B. Owens, and R. F. Worcester, Deep water formation in the Greenland Sea, Oceanus, 37, 9-11, 1994.

Raach, S., and D. Etling, Modeling deep ocean convection: Large eddy simulation in comparison with Laboratory experiments, J. Phys. Oceanogr., 28, 1786-1802, 1998 .

Shuhy, J. L., Oceanographic observations: North Atlantic Ocean Station Bravo, Oceanogr. Rep. CG 373-20, 400 pp., U. S. Coast Guard, Washington, DC, 1969.

Shuhy, J. L., Oceanographic observations: North Atlantic Ocean Station Bravo, Oceanogr. Rep. CG 373-63, 160 pp., U. S. Coast Guard, Washington, DC, 1974.

Søndergaard, M., P. J. B. Williams, G. Cauwet, B. Riemann, C. Robinson, S. Terzic, E. Malcolm, S. Woodward, and J. Worm, Net accumulation and flux of dissolved organic carbon and dissolved organic nitrogen in marine plankton communities, Limnol. Oceanogr., 45, 1097-1111, 2000.

Steffen, E. L., and A. D. D'Asaro, Deep convection in the Labrador Sea by Lagrangian floats, J. Phys. Oceanogr., 32, 475-492, 2002.

Suzuki, S., K. Kogure, and E. Tanoue, Immunochemical detection of dissolved proteins and their source bacteria in marine environments, Mar Ecol. Prog. Ser., 158, 1-9, 1997.

Tait, V. K., R. M. Gershey, and E. P. Jones, Inorganic carbon in the Labrador Sea: Estimation of the anthropogenic component, Deep Sea Res. Part I, 47, 295-308, 2000

Takahashi, T., T. T. Takahashi, and S. C. Sutherland, An assessment of the role of the North Atlantic as a $\mathrm{CO}_{2}$ sink, Philos. Trans. R. Soc. London, Ser. B, 348, 143-152, 1995

Tanoue, E., S. Nishiyama, M. Kamo, and A. Tsugita, Bacterial membranes: Possible source of a major dissolved protein in sea water, Geochim. Cosmochim. Acta, 59, 2643-2648, 1995.

Tans, P. P., L. Y. Fung, and T. Takahashi, Observational constraints on the global atmospheric $\mathrm{CO}_{2}$ budget, Science, 247, 1431-1438, 1990.

Thomas, H., V. Ittekkot, C. Osterroht, and B. Schneider, Preferential recycling of nutrients: The oceans way to increase new production and to pass nutrient limitation?, Limnol. Oceanogr., 44, 1999-2004, 1999.

Tian, R. C., et al., Effects of pelagic food-web interactions and nutrient remineralization on the biogeochemical cycling of carbon: A modeling approach, Deep Sea Res., Part II, 47, 637-662, 2000.

Tian, R. C., A. F. Vézina, M. Starr, and F. Saucier, Seasonal dynamics of coastal ecosystems and export production at high latitudes: A modeling study, Limnol. Oceanogr., 46, 1845-1859, 2001.

Tian, R. C., D. Debeil, R. B. Rivkin, and A. F. Vezina, Biogenic carbon and nitrogen export in a deep-convection: Simulations in the Labrador Sea Deep Sea Res., in press, 2003

Urban-Rich, J., Release of dissolved organic carbon from copepod fecal pellets in the Greenland Sea, J. Exp. Mar. Biol. Ecol., 232, 107-124, 1999.

D. Deibel and R. B. Rivkin, Ocean Sciences Center, Memorial University of Newfoundland, St. John's, NF A1C 5S7 Canada. (ddeibel@morgan. ucs.mun.ca; rrivkin@pop.morgan.ucs.mun.ca)

R. C. Tian, Department of Earth and Planetary Science, Harvard University, 20 Oxford Street, Cambridge, MA 02138, USA. (rtian@deas. harvard.edu)

A. F. Vézina, Bedford Institute of Oceanography, Department of Fisheries and Oceans, Challenge Drive, Dartmouth, NS B2Y 4A2 Canada. (vezinaa@ dfo-mpo.gc.ca) 